Rochester Institute of Technology

RIT Scholar Works

2013

Online Reading Informs Classroom Instruction and Promotes

Collaborative Learning

Leslie Kate Wright

Sacha Zyto

David R. Karger

Dina L. Newman 


\section{Online Reading Informs Classroom Instruction and Promotes Collaborative Learning}

\section{By L. Kate Wright, Sacha Zyto, David R. Karger, and Dina L. Newman}

Web-based collaborative annotation
tools can facilitate communication
among students and their
instructors through online reading and communication. Collaborative reading fosters peer interaction and is an innovative way to facilitate discussion and participation in larger enrollment courses. It can be especially powerful as it creates an environment where all students are able to ask questions and contribute to a discussion about science. An online annotation tool, Nota Bene (NB), was tested in two biology courses: intermediate-level Molecular Biology (89 students) and upper level Cancer Biology (26 students). Student participation in these graded reading assignments ranged from $79 \%$ to $93 \%$. A typical reading assignment from the upper level course generated 105 student comments, $68 \%$ of which led to responses, and a typical assignment from the midlevel course generated 183 comments, 44.8\% of which generated further discussion. NB also helped uncover misunderstandings and misconceptions about biological phenomena. Coded student responses revealed evidence of knowledge transfer and synthesis, especially in the upper level biology course. We suggest that this type of collaborative reading activity could be useful in a variety of postsecondary classroom settings as it encourages collaborative learning and promotes inclusion of students who might not participate otherwise.

$$
\text { orative learning through discussion, }
$$
broader participation, and deeper focus on class topics-hallmarks described by, among others, Guzdial and Turns (2000), Crouch and Mazur (2001), and Felder and Brent (2001). Web-based annotation systems allow students to read and comment on textbook passages, primary literature, and scientific reviews posted by a course instructor using a social media format. Online reading and dialogue may promote student learning through peer interaction (Vygotsky, 1978), as discussion under common frameworks allows students to apply resources and knowledge while being challenged to rethink or reflect on realization of inconsistent ideas and thoughts (Chiu, 2000, 2008). Webbased online annotation systems also promote the concept of universal instructional design; when instructional techniques benefit students with disabilities such as Deaf or Hard-ofHearing (D/HH) or English Language Learners (ELL), all students in the classroom benefit (Pliner \& Johnson, 2004). In a traditional classroom setting, D/HH and ELL students may shy away from asking questions or participating in discussions because they are unsure of their ability to pose a clear question in front of their peers or take longer to answer a question because they might have to translate between English and their native language. This obstacle is easily remedied using an online system that only requires reading and writing abilities.

Nota Bene (NB), which means "note well" in Italian and Latin, is an example of a web-based, in-place communal PDF annotation tool that is designed to improve student participation and learning in academic settings. Designed by Professor David Karger and his Haystack Group in the Computer Science and Artificial Intelligence Laboratory at MIT (Zyto, Kargar, Ackerman, \& Mahajan, 2012), this open-source tool (found at http:// nb.mit.edu) is user-friendly and was designed to promote active participation in large-enrollment courses. NB users can read and annotate PDF documents to highlight words/terms that may be confusing, post questions on content, respond to other questions posted by peers, and engage in discussion about topics in a "chat" format. Unlike other online discussion forums, such as discussion or chat tools commonly found in course management systems, NB has the advantage of allowing students to post/comment/ reply within the actual document they are reading. Students can post using their name or leave an anonymous post that can be visible to all or to instructors only. Users are later informed via e-mail when their post has been replied to, with a link back to the article. In certain aspects, the NB tool is similar to social media networks such as Facebook or Twitter, which are immensely popular with college students (Ellison, Steinfield, \& Lampe, 2007; Pempek, Yermolayeva, \& Calvert, 2009) and may also be a good choice when designing and implementing an online course. 
NB has currently been deployed in 32 mathematics, physics, and engineering courses at several large-enrollment universities, where investigators have found a high rate of student participation and various levels of engagement with the system (Zyto et al., 2012) in mathematics-based courses. Here we analyzed the NB system in two different biology courses at a predominantly undergraduate institution. We found that student participation on graded reading assignments was high, and students communicated with each other in a variety of ways. Coding student responses revealed evidence of higher order thinking, including knowledge transfer and synthesis, especially in the upper level biology course (Furst, 1981; Krathwohl, 2002). Our analysis suggests that NB is a useful tool to elicit student participation, promote peer engagement, and help inform classroom design.

\section{The students}

All student data, from undergraduate biology majors at a large private university, was gathered following in- stitutional review board guidelines, and informed consent was received from all participants. Pseudonyms have been used throughout to protect the identities of students. The online annotation tool NB was tested in two undergraduate biology courses: a midlevel Molecular Biology course $(N=89)$ and an upper level Cancer Biology course $(N=26)$. Both courses were offered during the same academic year but at different times and were instructed by the same faculty member. Students in each course were randomly placed into online reading groups of $13-15$ and were reassigned at least once during the academic quarter to shuffle students. NB reading assignments were graded activities in both courses. Students were typically given at least one week to read and complete NB assignments, which were spaced out over the course of the academic term. In each course, students were graded on a scale of $0-3$ for each NB assignment on the basis of effort. Student comments were analyzed after both courses were complete.

\section{NB in the classroom}

Once students accept an e-mailed invitation to NB and create a username, they have access to PDF documents (uploaded by instructor) in their class folder. Dialogue boxes can be opened with a mouse click, and users have the ability to highlight any text they wish to comment on (Figure 1). Because the reading material and the online discussions are linked, it is easy to understand the context of each post. Users are also notified, via e-mail, when another user has replied to one of their posts, and they are presented with a link back to the online document. This feature, which can also be turned off, has the advantage of bringing the user back to the reading material with one click of the mouse, which may promote further online discussion or at least rereading of some material.

\section{Reading assignments and student participation}

Student participation in graded NB reading assignments was high, ranging from $80 \%$ to $93 \%$ (Table 1). As-

\section{FIGURE 1}

\section{Screen shot of reading assignment and annotation window using the Nota Bene online tool.}
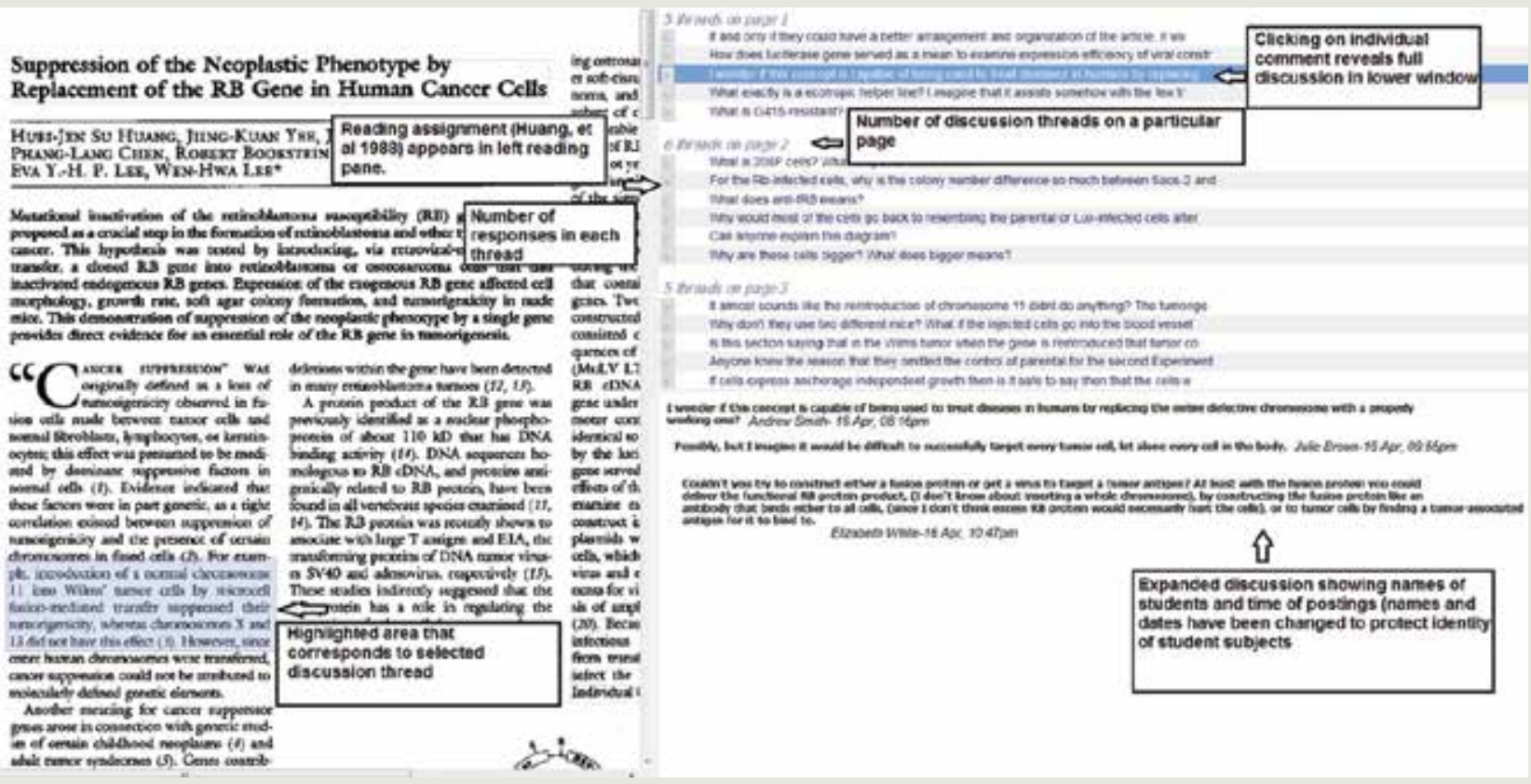
signments for the Molecular Biology course were mainly textbook passages and review articles intended for an undergraduate audience, whereas assignments for the upper level Cancer Biology course consisted mainly of landmark primary literature articles and review articles written for clinicians. Participation in collaborative reading assignments was graded and counted for $10 \%$ of each final course grade. Students were graded on a scale of $0-3$ for their efforts, and they were told that a score of 3 would be awarded when they "made a real effort and contributed to the conversation." Students were not instructed on how many times they had to post or what kinds of com- ments they should make. A student who posted/commented three or more times with something substantive, for example, would get a 3 , and a student with only one comment would get a 1 . The grading on each assignment took the instructor from 30 to 45 minutes. The intentional vagueness most likely encouraged more participation, as students were not entirely sure what "real effort" looked like. When the Molecular Biology exam review material was posted on NB as optional material, less than $10 \%$ of students opened or commented on the review material. This finding suggests that, unsurprisingly, students are motivated directly by grade incentives, even when the incentive makes up a small percentage of their final average.

\section{Analysis of student comments}

Comments $(N=386)$ from four articles were analyzed to determine how many comments led to online discussions. We found that students in the upper level course participated in more discourse; nearly three quarters of all initial comments generated a discussion in that course. However, less than half ( $37 \%$ and $45 \%)$ of comments in the midlevel course were replied to by a peer (Figure 2). On all assignments, the instructor made it a point to respond to at least $10 \%$ of the comments, being sure

\section{TABLE 1}

\section{Reading assignments and rate of student participation from a midlevel Molecular Biology (MB) and upper}

level Cancer Biology (CB) course.

\begin{tabular}{|l|l|l|l|}
\hline Reading assignment & Course & Reference & $\begin{array}{l}\text { Student } \\
\text { participation }\end{array}$ \\
\hline Isolating Hereditary Material & $\mathrm{MB}$ & $\begin{array}{l}\text { Educational review article } \\
\text { (O'Connor, 2008) }\end{array}$ & $87 \%$ \\
\hline Nucleic Acids and Rules of Carpentry & $\mathrm{MB}$ & $\begin{array}{l}\text { Textbook passage } \\
\text { (Alberts et al., 2002) }\end{array}$ & $91 \%$ \\
\hline Chromosomal DNA and Packaging & $\mathrm{MB}$ & $\begin{array}{l}\text { Textbook passage } \\
\text { (Alberts et al., 2002) }\end{array}$ & $84 \%$ \\
\hline $\begin{array}{l}\text { Deficient DNA Mismatch Repair: A Common Etiologic Factor for Colon } \\
\text { Cancer }\end{array}$ & $\mathrm{MB}$ & $\begin{array}{l}\text { Educational review article } \\
\text { (Peltomäki, 2001) }\end{array}$ & $80 \%$ \\
\hline $\begin{array}{l}\text { What is a Gene? Colinearity and Transcription Units } \\
\text { Translation: DNA to mRNA to Protein }\end{array}$ & $\mathrm{MB}$ & $\begin{array}{l}\text { Educational review article } \\
\text { (Pray, 2008) }\end{array}$ & $93 \%$ \\
\hline $\begin{array}{l}\text { Complex Formation of Human Papillomavirus E7 Proteins With the } \\
\text { Retinoblastoma Tumor Suppressor Gene Product }\end{array}$ & $\mathrm{CB}$ & $\begin{array}{l}\text { Educational review article } \\
\text { (Clancy \& Brown, 2008) }\end{array}$ & $92 \%$ \\
\hline $\begin{array}{l}\text { Isolation of a Transforming Sequence From a Human Bladder } \\
\text { (Murcinoma Cell Line }\end{array}$ & $\mathrm{CB}$ & $\begin{array}{l}\text { Primary literature } \\
\text { (Shih \&Weinberg, 1982) }\end{array}$ & $85 \%$ \\
\hline $\begin{array}{l}\text { ABC of Breast Diseases: Breast Cancer-Epidemiology, Risk Factors, } \\
\text { and Genetics }\end{array}$ & $\mathrm{CB}$ & $\begin{array}{l}\text { Clinical review article } \\
\text { (McPherson, 2000) }\end{array}$ & $81 \%$ \\
\hline $\begin{array}{l}\text { Evidence From Randomised Trials on the Long-Term Effects of } \\
\text { Hormone Replacement Therapy }\end{array}$ & $\mathrm{CB}$ & $\begin{array}{l}\text { Clinical review article } \\
\text { (Beral, Banks, \& Reeves, } \\
\text { 2002) }\end{array}$ & $89 \%$ \\
\hline $\begin{array}{l}\text { Suppression of the Neoplastic Phenotype by Replacement of the RB } \\
\text { Gene In Human Cancer Cells }\end{array}$ & $\mathrm{CB}$ & $\begin{array}{l}\text { Primary literature } \\
\text { (Huang et al., 1988) }\end{array}$ & $85 \%$ \\
\hline
\end{tabular}


to interact with different students from each reading group. This seemed to be an effective way to stay connected with a large class.

Following is some of the interaction between Cancer Biology students discussing the McPherson's (2000) clinical review, "ABC of Breast Diseases." Here the discussion centered on passages related to hormone replacement therapy (HRT) and breast cancer risk:

Shania: This goes back to my first question, why is there an increase in use of HRT in postmenopausal women if there are awful risks associated with it? Linda (reply): There is an increase in HRT due to other benefits, not because of these risks. Benefits of HRT in women include stronger bones. There are many women who are more concerned about osteoporosis than about breast cancer.

Elise (reply): It sounds like choosing between the lesser of two evils. But which should be considered the worst option? Katherine (reply): It sounds like most women believe the guaranteed benefits of HRT are worth the risk of cancer.

We included this passage because it is an example of an authentic discussion about a scientific topic that students seem to care about. Examining the online conversation surrounding a particular reading may help an instructor facilitate a better in-class discussion about

\section{FIGURE 2}

Students often engage in online discussion using Nota Bene. The percentage of comments that led to further online discussion were analyzed from two different reading assignments in the Molecular Biology (MB) and Cancer Biology (CB) courses.

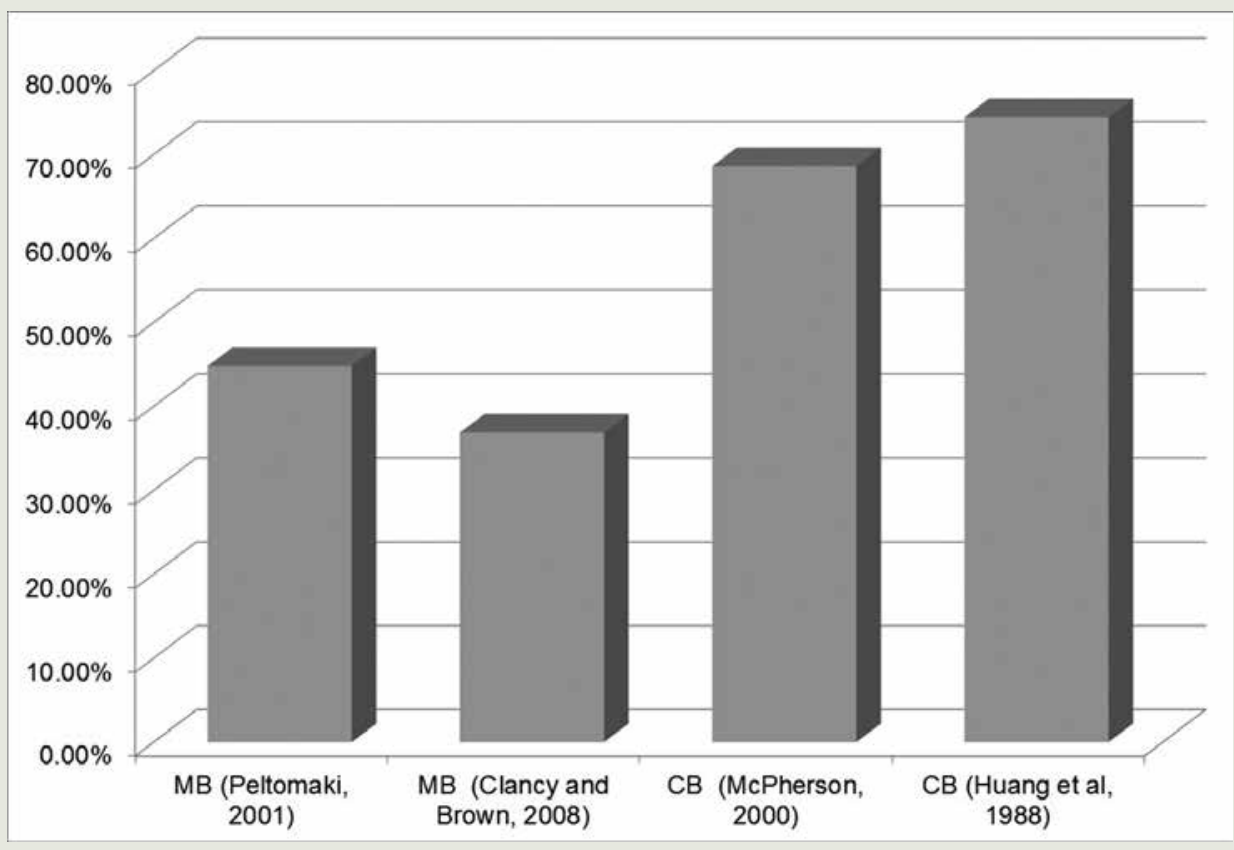

\section{FIGURE 3}

Students communicate in various ways using Nota Bene (NB). Student comments from two NB reading assignments, from the Molecular Biology (Mol Bio) and Cancer Biology (Cancer Bio) course were coded to using an emergent scheme. The majority of comments were classified as observational or interpretation questions, but students also respond to posted questions and engage in sidebar (scientific) discussions. Although the instructor did reply and join various online discussions, none of the instructor's comments were included in this analysis.

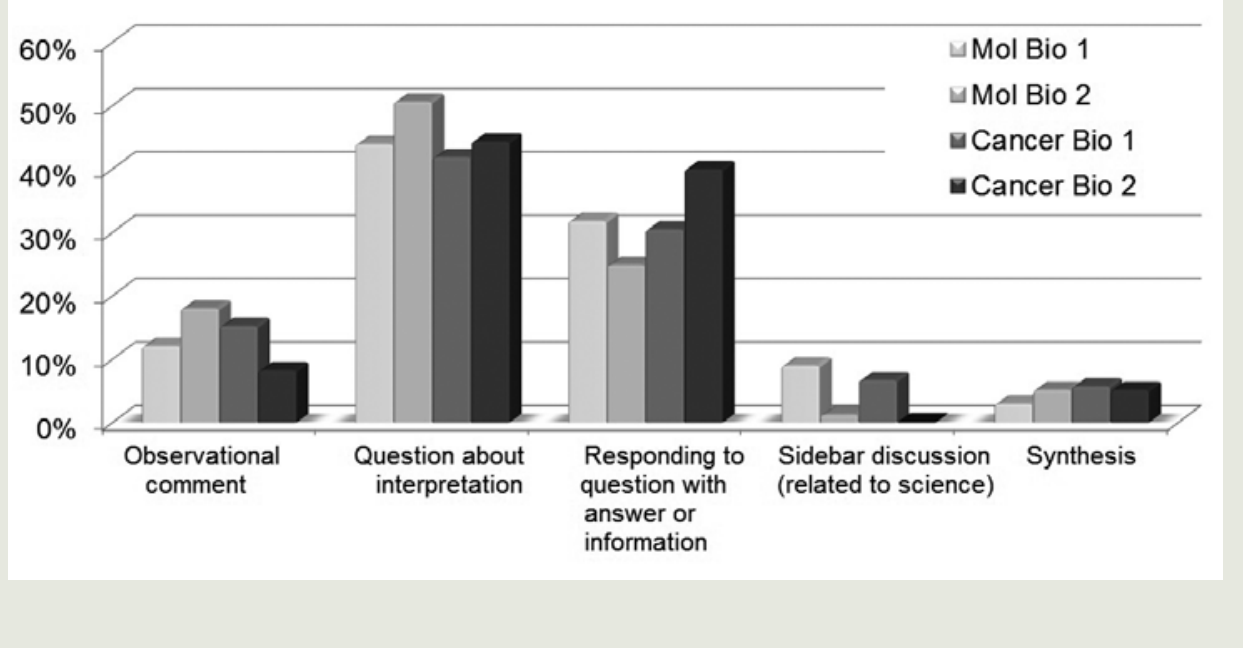


something the students have a genuine interest in, rather than focusing on a topic that an instructor assumes would be interesting to the class. Analysis of online conversation may also be a way to determine conceptual understanding about a particular area. As suggested by Garvin-Doxas and Klymkowsky (2008), the best way to get students to reveal their true understanding is to allow them to use their "natural language rather than the technical language they learn in their courses" (p. 228).

All student comments from the same four reading assignments were analyzed using an emergent scheme to classify discourse (Figure 3). Regardless of the course or assignment, almost half of all posts were questions about interpretation or content in the reading material. Although not all student questions were answered by peers, $25 \%$ and $30 \%$, respectively, were answered from the two Molecular Biology assignments and $30 \%$ and $40 \%$, respectively, were answered in the Cancer Biology course. This type of dialogue is exemplified in the following passage from Molecular Biology students discussing chromatin structure and DNA packaging (Alberts, Johnson, \& Lewis, 2002):

Jenna: What about nuclease gives it an affinity for the linker DNA but not the DNA wound tightly around the core? Is it just that the linker DNA is more exposed?

Katelyn (reply): Nuclease is an enzyme. Enzymes have a specific site in which the DNA binds. For this enzyme to work it needs to have the DNA be able to access this site. Thus, it is easier for the linker DNA to fit into the substrate binding site. It is very difficult for this to occur when wrapped tightly around the core.

Different students from the same course discuss a passage about AUG translational start codons from Clan- cy and Brown's (2008) “Translation: DNA to mRNA to Protein." Dawson provides a sophisticated yet easy-tofollow answer to Owen's question that incorporates core concepts in evolution and energy:

Owen: Is there a specific reason for this? As in did this arise as result of certain chemical factors? . . . I mean why AUG as the start codon, why not another?

Dawson (reply): It's to some degree arbitrary, as most things are. Though, if there was a reason we may never know what it was, as the whole "RNA world" period of life is an extremely foggy topic. The best that can be said is that during the transition RNA to DNA storage, methionine was a favored pathway for beginning protein synthesis. Perhaps there were other, but for whatever reason AUG persisted and its cascade proved most efficient.

In both examples students took on the role of instructor and the actual course instructor took on the role of facilitator in the learning process. Students occasionally engaged in sidebar conversation related to science but not directly related to the content of the reading material, as seen in this online exchange among five students in the Cancer Biology course:

Lee: I found this paragraph interesting and true. Back in centuries, especially in my country Malaysia that the women around 1970s and 1980s did get married and give birth to average 10 children at relatively low age that might dramatically reduce their risk of getting breast cancer as mentioned in this paragraph.

Linda (reply): That is really interesting. I was wondering if women in Malaysia do hormone replacement therapy (women who have reached menopause or have had hysterectomies)? I know that HRT is quite common in the United States so I was wondering if it was also widely used in countries such as yours.

Kazin (reply): Probably not common in Malaysia. People in Malaysia don't get as much exposure to various drugs like here in the U.S. Tuan (reply): I think that it is not common in Malaysia. People only do HRT for some of the medical treatment.

Melissa (reply): Do you happen to know if any other types of cancer were a problem for Malaysian women during that time period, particularly cervical cancer? I know that having a lot of children, especially at a younger age, can put a woman at risk for cervical cancer. That, and from the few studies I've seen on breast and cervical cancer, it seems like the risks for both types of cancer are inversely proportional to each other.

This exchange is highlighted because social interaction (i.e., peerpeer conversation) is tightly linked with cognitive development (Vygotsky, 1978). Although the students were discussing an idea that was not directly part of their reading or course curricula, we reason that these discussions most likely had a positive impact on their learning, as well as contributing to a sense of community.

Students occasionally also demonstrated synthesis of new knowledge. This higher order cognitive skill (Furst, 1981; Krathwohl, 2002) is demonstrated by following passages from students in the Cancer Biology course. Below, Aiden comes to the conclusion that dysfunctional breast cancer-causing genes do not just play a role in breast cancer because they also function in other cells and tissue types:

Aiden: So what I'm getting with this is that since women with breast 
cancer and some other epithelial cancer are more likely to have a gene that causes breast cancer, that means that breast cancer causing genes are nonspecific, since they can cause different types of cancer. Is that right/does that make sense? Megan (reply:) That's sort of what I'm getting. Mutations in genes that have functions in many different areas could potentially contribute to cancer in any those areas.

Knowledge synthesis was also evident from a Molecular Biology student reading an assignment about gene expression. Several students discussed the concept of a "promoter," a dedicated sequence of DNA that interacts with transcription factors and RNA polymerase to facilitate transcription of RNA from the DNA template (Watson et al., 2004). A student comes to the conclusion that a mutation, or change in the DNA sequence, in the promoter region may have an effect on gene expression:

Heather: So if there was a genetic mutation in the promoter, I assume that it would be detrimental to the protein, since it would never get made.

Most instructional materials use examples of mutations that occur in the protein coding regions of genes to describe the results of silent, nonsense, or missense mutations (Carlin, 2011; Watson et al., 2004), but in reality mutations are not restricted to these regions. We argue that Heather's statement demonstrates knowledge synthesis as she was able to create a new (and correct) idea from several different concepts.

Although not coded as a separate category, students also demonstrated evidence of knowledge transfer: application of knowledge to a new context (Bransford \& Schwartz, 1999). Although Angela posts a comment that demonstrates confusion about genetic information flow and the evolution from an RNA to DNA world (Bartel \& Unrau, 1999; Gesteland, Cech, \& Atkins, 2006), her classmate, Cassie, replies with a rather sophisticated answer that demonstrates knowledge transfer:

Angela: Are there any primitive organisms that use genomic DNA to form proteins rather than RNA? Cassie (reply): I would guess that they do not have a membranebound nucleus. Otherwise there would be a huge buildup of proteins within the nucleus.

Although this idea was not discussed in class or in the reading material, Cassie is correct in her thinking. DNA is not just housed within the nuclear structure of eukaryotic cells; it never leaves the nucleus. Cassie, we assume, had knowledge of the process of cellular protein trafficking and realized that a membrane-bound nucleus would be detrimental to a cell that somehow had the ability to synthesize protein using a DNA template.

In the next exchange, Lynn and Mason discuss a landmark Cancer Biology manuscript (Shih \& Weinberg, 1982) that describes the first identification of an oncogenic, or cancer-promoting, DNA sequence from mammalian tumor cells. Lynn is confused because the authors wrote that "The oncogene appears to derive from sequences present in normal cellular DNA" (p. 161). Mason offers an alternate, and valid, explanation for oncogenic transformation that has been described in the literature (Schimke, 1984; Lahortiga et al., 2007) involving gene duplication (adding new genetic material) and not an actual mutation or change in the DNA sequence:

Lynn: I am confused by this. Wouldn't a mutation be present to make this segment an oncogene? If it is the same as the normal cellular DNA then why is it acting as an oncogene ... is there something else that is causing this gene to be an oncogene?

Mason (reply): I have to agree on this. It is a bit confusing. But there doesn't have to be a mutation in the gene itself to make it an oncogene. What could have happened was gene duplication and this caused that gene to be in two places in the genome and double its normal production of protein which causes it to act like an oncogene without changing the protein made.

We categorize Mason's response as knowledge transfer because it is evident he understands something about gene duplication and is able to make a rational argument for this alternative mechanism of oncogene transformation. Gene duplication was not, at this point in the course, an explicit topic of discussion, but Mason was able to successfully use his understanding of gene duplication, possibly from a genetics or evolution course, in this new situation.

\section{Uncovering misconceptions/ misunderstandings}

NB was a useful tool because it offered a sneak peek into the minds of the students, especially in the midlevel Molecular Biology course. Although the instructor correctly anticipated some areas of confusion, using NB highlighted concepts or language confusion that the instructor did not predict. An early reading assignment about landmark work in the field of molecular biology (O'Connor, 2008) generated a number of student replies and questions concerning a statement the author made about DNA being able to "renature" after heat treatment. In this passage the author was referring to the ability of a heat-denatured, or single-stranded 
DNA, to reform a double-stranded helix at cool temperatures (Cavalieri, Small, \& Sarkar, 1962; Wetmur \& Davidson, 1968). We found that some students such as Ellie thought that DNA behaved like a protein would at high heat:

Ellie: If it can renature after heat treatment, then how does it make sense that we can die from very high fevers? If someone had a very high fever, high enough to die from but the fever was brought down, would the molecules renature?

Some students were confused about the concept of bonding and its role in the molecular structure of DNA. Covalent linkages present in the sugar-phosphate backbone of the molecule are not affected by the heat conditions described in the reading. The noncovalent interactions (Hydrogen bonds) between complementary bases are. Norman, in the next example, offers a backward explanation to the question of how DNA molecules can renature; hydrogen bonds are reformed, not broken:

Andrew: I had no idea that DNA could renature after heat treatment. Annie: How do DNA molecules renature?

Norman (reply): Breaking of the hydrogen bond?

There was also confusion about the scientific term denature, defined as (1) having been altered in natural quality and (2) of, or pertaining to, a molecule (such as a protein or a nucleic acid) wherein its chemical structure is altered through chemical or physical means so that some of its original properties are lost or diminished (biology-online.org). Some students replaced the scientific definition of denature with the meaning of everyday words destroy and degrade. A novice may consider the term denature to be synonymous with destroy and degrade, but an expert uses scientific vocabulary more carefully as when the author (O'Connor, 2008) wrote "Today we know that DNA can renature after heat treatment."

Cassie: I didn't know that! Amy (reply): I didn't either, I was under the impression that once it was denatured the structure was completely destroyed.

Monica: I was also under the same impression. What allows DNA to do this?

Cassie (reply): Maybe when DNA denatures, only the two strands are separated, and the individual strands themselves are not damaged, thus making it possible to renature.

Cassie finally makes a structurefunction connection that accurately describes the behavior of a DNA molecule subjected to temperatures high enough to break the hydrogen bonds between complementary bases. Considering that DNA structure and function is a main focus of a Molecular Biology course, it was extremely helpful for the instructor to "hear" ideas students were bringing into the classroom.

In another example of language confusion, students engaged in a discussion about protein translation bring up the idea of nonessential versus essential amino acids. The label of nonessential refers to amino acids for which biosynthetic pathways exist in humans. Essential amino acids, on the other hand, must be acquired through dietary intake (Umbarger, 1978; Viola, 2001). Two students ask questions about the difference between essential and nonessential amino acids, with Brody and Yolanda adding to the conversation:

Brody (reply): There are 20 "essential" amino acids which are used in the body for protein synthesis. Yolanda: If the other nonessential amino acids stop being transcribe[d] in to protein, would our system be affected? Why do we produce this other nonessential amino acids if we don't need them? Could it be like a back-up plan in case any of the other essential amino acids is mutated?

Both students appear to be misinterpreting the term essential for the nonbiological vernacular (important) and consider all amino acids essential for protein synthesis. Yolanda also incorrectly describes protein translation as something "being transcribe[d]" and talks about amino acids that are "mutated," a term that should be reserved for DNA. Yolanda's idea seems to be that cells have a mechanism to substitute alternative amino acids into the protein translation process when needed, like a back-up mechanism.

\section{Student perceptions}

After both courses were finished, all students were invited to participate in an online survey using a modified Student Assessment of Learning Gains instrument (Seymour, Wiese, Hunter, \& Daffinrud, 2007). Students were asked, using Likert-scale responses, about the impact that NB made on their learning, understanding, confidence, and participation. As demonstrated by Figure 4, 43 students responded, with the majority reporting that the tool helped them make great to moderate gains in their confidence, enthusiasm, and interest and in their understanding of main concepts and how they were related to each other. Using the system also encouraged them to ask questions and to participate in online discussions of the material.

\section{Discussion}

Instruction can be effective only when educators listen and find ways to learn what students are thinking 
(Redish \& Steinberg, 1999). NB may help an instructor glimpse the mental models and ideas students bring into their classroom and identify problematic concepts or scientific terminology. Language is essential to communicating clearly, but novices often misuse or misapply both scientific and "everyday" words when learning or describing complex scientific processes. Chemists, for example, recognize that an "ideal gas" is a hypothetical gas that obeys Boyle's and Charles' Laws at all temperatures and at all pressures. The word ideal in nonchemistry language, though, describes something that has complete perfection. We found evidence of this in a molecular biology setting when students interchanged the definition of nonscientific terms destroy and degrade for the scientific word denature. Using the incorrect definitions of words used in a scientific context leads to incorrect reasoning and misunderstanding about the behavior of DNA. Using the NB tool was useful, then, for directing classroom discussion and activities around problematic topics or language misuse.

Our analysis also revealed that students communicated with each other in a variety of ways that sometimes shifted the culture of a classroom from instructor centered to student centered. As described by J. W. Schofield (1995, 1997), an instructor's role can be changed from authority figure to facilitator when a technology-based tool is brought into the classroom. We argue that students in the classroom demonstrated, at least during online sessions, more

B

\section{FIGURE 4}

\section{Students $(N=43)$ reported that Nota Bene (NB) positively impacted their learning using the Student Assessment of Learning Gains. Students were asked about gains (in learning and confidence) that resulted from using NB in class (A) and how much NB assignments helped their learning (B).}

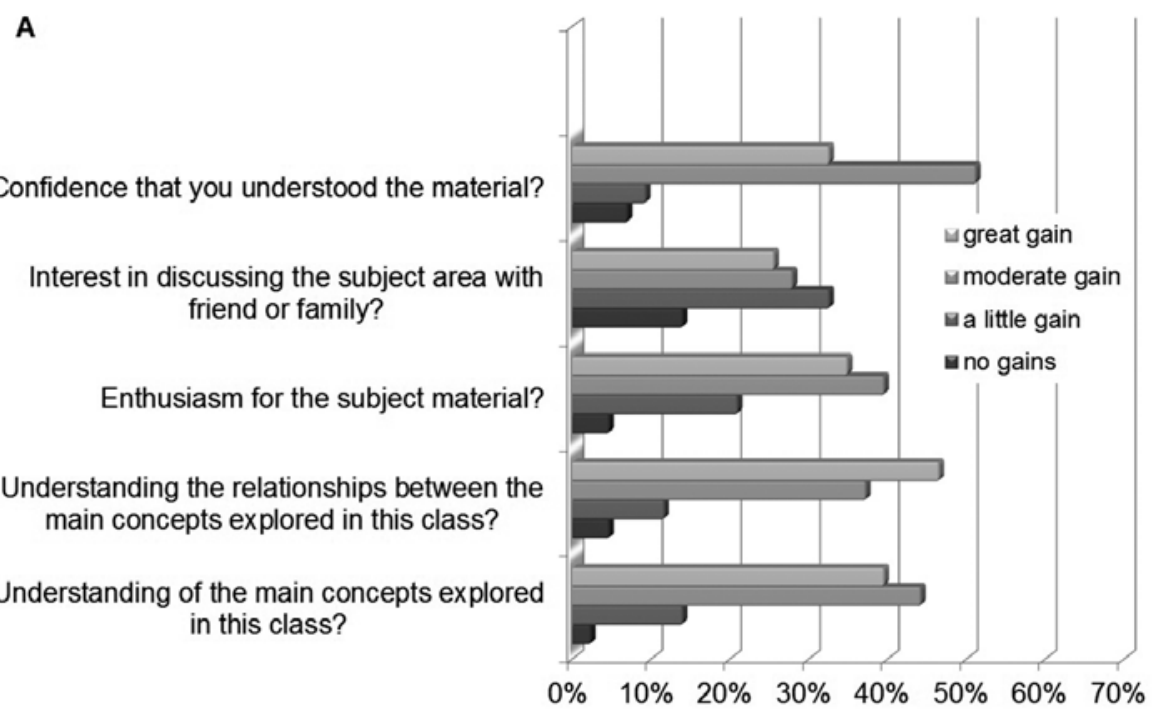

Encouraging me to ask questions?

Encouraging me to participate in discussion and reading assignments?

Encouraging me to attend class?

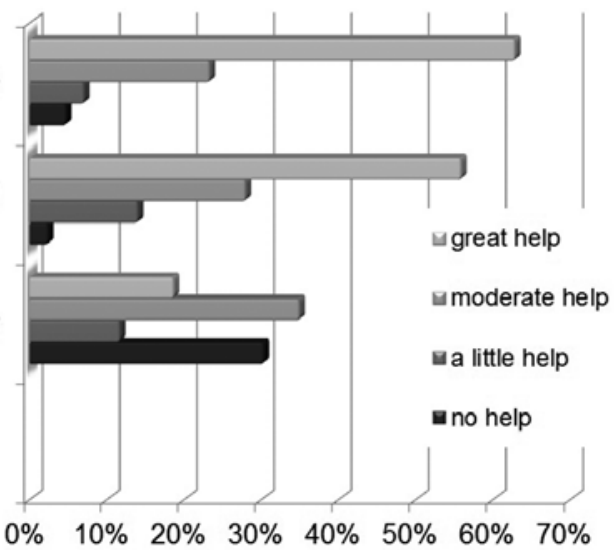

dependence on each other than on the instructor, especially in the upper division course. Thus, using an online annotation and discussion tool may help an instructor seeking ways to transition from an authority figure to a facilitator. Student participation with NB was incredibly high, most likely due to the grade incentive, and students reported the tool helped them understand main concepts, encouraged them to ask questions, and helped them gain confidence and interest in the subject material.
As described in numerous publications (Iyengar et al., 2008; Krathwohl, Bloom, \& Masia, 1973; National Research Council, 1997; Palmer \& Devitt, 2007; Zheng, Lawhorn, Lumley, \& Freeman, 2008), one of the goals of undergraduate STEM education is to facilitate the development of scientific reasoning skills, critical thinking, and problem solving-skills that can be transferred to real-world situations like in the ever-changing world of scientific research and in professional careers. 
An online annotation tool, such as $\mathrm{NB}$, could also be used as an assessment instrument to track individual or class progress in both content knowledge and cognitive ability by the kinds of comments they post and how they respond to other posted questions. Because of its extremely open-ended nature, an online annotation tool used to elicit student ideas and course artifacts could also be applied to research into thinking and learning (Mestre, 2005).

As described by those in the education field, effective pedagogies should not be discipline dependent but should be easily transferrable between academic spheres (Pascarella \& Terenzini, 2005). These pedagogies should encourage active learning and collaboration, which can result in improved student learning (Kuh, Kinzie, Buckley, Bridges, \& Hayek, 2007; Kuh, Kinzie, Schuh, $\&$ Whitt, 2005). In addition to fulfilling the requirements of an effective pedagogical strategy, NB does not require additional financial resources and can be implemented into a variety of classroom settings, which are important considerations for instructors interested in this tool (Fairweather, 2008). Online collaborative tools may also allow for enhanced learning and participation opportunities for disadvantaged students and promotes the concept of universal instructional design; when instructional techniques benefit students with disabilities (D/HH, ELL or shy and withdrawn students), all students in the classroom benefit (reviewed by Pliner \& Johnson, 2004).

\section{Acknowledgment}

We thank Andrew Berger and Thomas Kim for helpful discussions about the manuscript.

\section{References}

Alberts, B., Johnson, A., \& Lewis, J. (2002). Molecular biology of the cell (4th ed.). New York, NY: Gar- land Sciences.

Bartel, D. P., \& Unrau, P. J. (1999). Constructing an RNA world. Trends in Biochemical Sciences, 24, M9M13.

Beral, V., Banks, E., \& Reeves, G. (2002). Evidence from randomised trials on the long-term effects of hormone replacement therapy. Lancet, 360, 942-944.

Bransford, J. D., \& Schwartz, D. L. (1999). Chapter 3: Rethinking transfer: A simple proposal with multiple implications. Review of Research in Education, 24, 61-100.

Carlin, J. L. (2011). Mutations are the raw materials of evolution. Nature Education, 3(10), 10.

Cavalieri, L. F., Small, T., \& Sarkar, N. (1962). The renaturation of denatured DNA. Biophysical Journal, 2, 339-350.

Chiu, M. M. (2000). Group problemsolving processes: Social interactions and individual actions. Journal for the Theory of Social Behaviour, 30, 26-49.

Chiu, M. M. (2008). Flowing toward correct contributions during group problem solving: A statistical discourse analysis. Journal of the Learning Sciences, 17, 415-463.

Clancy, S., \& Brown, W. (2008). Translation: DNA to mRNA to protein. Nature Education, 1(1). Available at http://www.nature. com/scitable/topicpage/translationdna-to-mrna-to-protein-393

Crouch, C. H., \& Mazur, E. (2001). Peer instruction: Ten years of experience and results. American Journal of Physics, 69, 970-977.

Ellison, N. B., Steinfield, C., \& Lampe, C. (2007). The benefits of Facebook "friends": Social capital and college students' use of online social network sites. Journal of Computer-Mediated Communication, 12, 1143-1168.

Fairweather, J. (2008). Linking evidence and promising practices in science, technology, engineering, and mathematics (STEM) undergraduate education: A status report for the National Academies National Research Council Board of Science Education. Washington, DC: National Academies Press.

Felder, R., \& Brent, R. (2001). Effective strategies for cooperative learning. Journal of Cooperation and Collaboration in College Teaching, 10, 69-75.

Furst, E. J. (1981). Bloom's taxonomy of educational objectives for the cognitive domain: Philosophical and educational issues. Review of Educational Research, 51, 441-453.

Garvin-Doxas, K., \& Klymkowsky, M. W. (2008). Understanding randomness and its impact on student learning: Lessons learned from building the Biology Concept Inventory (BCI). CBE-Life Sciences Education, 7, 227-233.

Gesteland, R. F., Cech, T., \& Atkins, J. F. (2006). The RNA world: The nature of modern RNA suggests a prebiotic RNA world. Cold Spring Harbor, NY: CSHL Press.

Guzdial, M., \& Turns, J. (2000). Effective discussion through a computermediated anchored forum. Journal of the Learning Sciences, 9, 437-469.

Huang, H. J., Yee, J. K., Shew, J. Y., Chen, P. L., Bookstein, R., Friedmann, T., . . Lee, W. H. (1988).

Suppression of the neoplastic phenotype by replacement of the RB gene in human cancer cells. Science, 242, 1563-1566.

Iyengar, R., Diverse-Pierluissi, M. A., Jenkins, S. L., Chan, A. M., Devi, L.A., Sobie, E.A., . . . Weinstein, D.C. (2008). Integrating content detail and critical reasoning by peer review. Science, 319, 1189-1190.

Krathwohl, D. R. (2002). A revision of Bloom's Taxonomy: An overview. Theory Into Practice, 41, 212-218.

Krathwohl, D. R., Bloom, B. S., \& Masia, B. B. (1973). Taxonomy of educational objectives. Handbook II: Affective domain. New York, 
NY: David McKay.

Kuh, G. D., Kinzie, J., Buckley, J. A., Bridges, B. K., \& Hayek, J. C. (2007). Piecing together the student success puzzle: Research, propositions, and recommendations (Ashe Higher Education Report Series). ASHE Higher Education Report, 32(5). San Francisco, CA: JosseyBass.

Kuh, G. D., Kinzie, J., Schuh, J. H., \& Whitt, E. J. (2005). Student success in college: Creating conditions that matter. San Francisco, CA: JosseyBass.

Lahortiga, I., De Keersmaecker, K. D., Van Vlierberghe, P. V., Graux, C., Cauwelier, B., Lambert, F., . . . Cools, J. (2007). Duplication of the MYB oncogene in T cell acute lymphoblastic leukemia. Nature Genetics, 39, 593-595.

McPherson, K. (2000). ABC of breast diseases: Breast cancer-epidemiology, risk factors, and genetics. British Medical Journal, 321, 624-628.

Mestre, J. P. (2005). Transfer of learning from a modern multidisciplinary perspective. Charlotte, NC: Information Age Publishing.

Münger, K., Werness, B. A., Dyson, N., Phelps, W. C., Harlow, E., \& Howley, P. M. (1989). Complex formation of human papillomavirus E7 proteins with the retinoblastoma tumor suppressor gene product. EMBO Journal, 8, 4099-4105.

National Research Council. (1997). Science teaching reconsidered: $A$ handbook. Committee on Undergraduate Science Education. Washington, DC: The National Academies Press.

O'Connor, C. (2008). Isolating hereditary material: Frederick Griffith, Oswald Avery, Alfred Hershey, and Martha Chase. Nature Education, 1(1). Available at http://www. nature.com/scitable/topicpage/ isolating-hereditary-materialfrederick-griffith-oswald-avery-336

Palmer, E., \& Devitt, P. (2007). As- sessment of higher order cognitive skills in undergraduate education: Modified essay or multiple choice questions? BMC Medical Education, 7, 49.

Pascarella, E. T., \& Terenzini, P. T. (2005). How college affects students: A third decade of research. San Francisco, CA: Jossey-Bass.

Peltomäki, P. (2001). Deficient DNA mismatch repair: A common etiologic factor for colon cancer. Human Molecular Genetics, 10, 735-740.

Pempek, T. A., Yermolayeva, Y. A., \& Calvert, S. L. (2009). College students' social networking experiences on Facebook. Journal of Applied Developmental Psychology, 30, 227-238.

Pliner, J., \& Johnson, J. R. (2004). Historical, theoretical, and foundational principles of universal instructional design in higher education. Equity \& Excellence in Education, 37, 1005-1113.

Pray, L. (2008). What is a gene? Colinearity and transcription units. Nature Education, 1(1). Available at http://www.nature.com/scitable/ topicpage/what-is-a-gene-colinearity-and-transcription-430

Redish, E. F., \& Steinberg, R. N. (1999). Teaching physics: Figuring out what works. Physics Today, 52, 24-30.

Schimke, R. T. (1984). Gene amplification, drug resistance, and cancer. Cancer Research, 44, 1735-1742.

Schofield, J. W. (1995). Computers and classroom culture. New York, NY: Cambridge University Press.

Schofield, J. W. (1997). Psychology: Computers and classroom social processes - a review of the literature. Social Science Computer Review, 15, 27-39.

Seymour, E., Wiese, D., Hunter, A.-B., \& Daffinrud, S. (2007, March). Creating a better mousetrap: Online student assessment of their learning gains. Paper presented at the national meeting of the Ameri- can Chemical Society, San Francisco, CA.

Shih, C., \& Weinberg, R. (1982). Isolation of a transforming sequence from a human bladder carcinoma cell line. Cell, 29, 161-169.

Umbarger, H. E. (1978). Amino acid biosynthesis and its regulation. Annual Review of Biochemistry, 47, 533-606.

Viola, R. E. (2001). The central enzymes of the aspartate family of amino acid biosynthesis. $A c$ counts of Chemical Research, 34, 339-349.

Vygotsky, L. S. (1978). Mind in society: The development of higher psychological processes. Cambridge, MA: Harvard University Press.

Watson, J. D., Baker, T. A., Bell, S. P., Gann, A., Levine, M., \& Losick, R. (2004). Molecular biology of the gene (5th ed.). Cold Spring Harbor, NY: CHSL Press.

Wetmur, J. G., \& Davidson, N. (1968). Kinetics of renaturation of DNA. Journal of Molecular Biology, 31, 349-370.

Zheng, A., Lawhorn, J., Lumley, T., \& Freeman, S. (2008). Application of Bloom's taxonomy debunks the "MCAT Myth." Science, 319, 414-415.

Zyto, S., Kargar, D., Ackerman, M., \& Mahajan, S. (2012, May). Successful classroom deployment of a social document annotation system. Paper presented at the SIGCHI Conference on Human Factors in Computing Systems, Austin, TX.

L. Kate Wright (Ikwsbi@rit.edu) is an assistant professor and Dina L. Newman is an assistant professor, both in the Gosnell School of Life Sciences, Rochester Institute of Technology in Rochester, New York. Sacha Zyto is a graduate student and David R. Karger is a professor, both in the Computer Science and Artificial Intelligence Laboratory, Massachusetts Institute of Technology, in Cambridge, Massachusetts. 